\title{
EDITORIAL
}

\section{Dossiês em perspectiva}

Dossiers in Perspective

Antes de adentrar o tema escolhido para este Editorial (a organização de dossiês), não podemos deixar de chamar a atenção para o fato de a Revista Brasileira de História vir a público num momento muito tenso da história do Brasil. Após a decisão do eleitorado no segundo turno em 28 de outubro de 2018, o presidente eleito Jair Messias Bolsonaro começa a definir seu Ministério e suas principais políticas para a gestão que começará em $1^{\circ}$ de janeiro de 2019. Entre as políticas anunciadas que causam justificadamente mais controvérsia estão: 1) a vinculação do Ensino Superior ao Ministério da Ciência e Tecnologia, saindo do Ministério da Educação (MEC); 2) o apoio à aprovação do Projeto de Lei 7180/2014, que institui a chamada "Escola sem Partido", ameaça à liberdade de ensino e uma forma de discriminar e, eventualmente, punir docentes por pretensos "delitos de opinião"; 3) a promessa de intervenção na autonomia universitária. Tudo isso significará, para a disciplina História, muitos desafios, e exigirá muita atenção e resistência. A Associação Nacional de História (Anpuh-Brasil) une-se a outras associações científicas no intuito de garantir a liberdade de pensamento e o crescimento da qualidade da pesquisa e do ensino de História.

A publicação de dossiês, ou seja, de conjuntos de artigos sobre uma mesma temática mais ou menos estrita, faz parte integrante dos periódicos acadêmicos e evoluiu em suas formas ao longo do tempo. Esse tipo de instrumento, mesmo se usado por títulos especializados, é de grande importância para publicações como a Revista Brasileira de História que, sumamente generalista, publica artigos sobre os mais variados temas. Os dossiês têm originalmente como função dar um estado da arte sobre o tema abordado. Mais ainda do que os próprios periódicos acadêmicos, que "fixam-se no presente", perdendo muitas vezes sua atualidade com o tempo, ${ }^{1}$ os dossiês estão claramente vinculados ao momento em que são publicados, pretendendo dar a ver novas abordagens de temas antigos, 
e também temas novos, em todo caso em sua abordagem histórica. Isso, é claro, apesar de tudo o que escrevemos estar fatalmente vinculado ao seu tempo.

Pode, no entanto, acontecer de dossiês se tornarem clássicos da historiografia, como é o caso daquele organizado neste periódico por Silvia Hunold Lara sob o tema da escravidão há exatos 30 anos. Tratava-se de aproveitar o centésimo aniversário da Lei Áurea não para comemorá-lo, mas para dar a ver temas até então pouco ou nada abordados pelos historiadores, como o da criança e da família escravas, ou o da diversidade regional mas também social da escravidão no Brasil (Lara, 1988). Os historiadores então convidados a colaborar com a revista, já eram ou rapidamente se tornariam referências nos estudos sobre a condição escrava no Brasil, assim como os textos que aqui publicaram. Pareceu natural que chegando os 130 anos da abolição, a mesma especialista do tema coordenasse mais um número da $R B H$, não só por conta da efeméride, mas igualmente pelo fato de o tema da escravidão contemporânea e as discussões de como defini-la e combatê-la preocuparem cada vez mais historiadores e cientistas sociais. ${ }^{2}$ No entanto, diferentemente do que foi feito 30 anos atrás, não se buscou mostrar a diversidade de temas passíveis de serem abordados em torno do tema da escravidão, mas, com o foco na importância das experiências individuais para a compreensão da realidade histórica, a chamada feita por Lara para o dossiê deste ano buscou incitar a produção de textos sobre como os próprios cativos e os libertos entendiam e viam suas condições. Tendo em vista o modo como são atualmente produzidos os dossiês, os resultados foram diferentes do esperado, mas nem por isso (muito pelo contrário) insatisfatórios, como a Apresentação que se segue a este Editorial claramente mostra.

As mudanças no modo como o dossiê devia ser elaborado de 30 anos para cá levam a pensar nas justificativas dessa organização. Com efeito, em 1988 Silvia Lara convidou individualmente os possíveis autores e com eles dialogou - antes e depois da recepção dos textos - sobre o conteúdo do que seria publicado. Outro modelo de dossiê (ou de coletânea, como eram chamados) era a publicação de trabalhos apresentados em conjunto em eventos acadêmicos, como no no 5 (1983), com publicações resultantes do encontro da diretoria da Anpuh durante a 34a reunião da Sociedade Brasileira para o Progresso da Ciência (SBPC), sobre o tema "Documentação e pesquisa histórica"; ou ainda o no 11 (1985/1986), com coletânea sobre "Sociedade e trabalho na História”, resultante do XIII Simpósio da Anpuh. Naquela época não se mobilizavam pareceristas, cabendo ao eventual organizador do dossiê, ao Editor e ao Conselho Editorial da revista decidirem sobre a relevância dos textos submetidos e, assim, sobre sua eventual aceitação ou recusa. O que se buscava, em 1988, era não só a qualidade dos textos, mas 
também certo diálogo entre eles e sua coesão, naquele caso relacionada à maior amplitude possível de abordagens.

Atualmente, os organizadores convidados elaboram a chamada do dossiê, que é aberta. Mesmo se um ou outro autor pode (e é) convidado a enviar um texto, sua submissão passa, como todos os demais textos da $R B H$, pelo processo de avaliação às cegas por pares. Uma primeira triagem feita pelo corpo editorial e pelos organizadores deixa de lado propostas que não se adequam à proposta do dossiê. Uma vez os textos retidos avaliados e aceitos pelos avaliadores, mesmo que condicionalmente, os organizadores também fazem correções e sugestões. Esse sistema de chamada universal e de avaliação às cegas, imposto pelas instâncias avaliadoras dos periódicos, tem como objetivo obter garantias da maior diversidade institucional dos autores e da maior isenção na avaliação possíveis. Ele tira uma parte do protagonismo dos organizadores, como de modo geral do próprio Editor, mas creio que apesar disso temos conseguido intervir positivamente nos dossiês. Se o sistema em uso poderia resultar em dossiês pouco coesos ou de relevância limitada, não é esse habitualmente o caso na $R B H$. Que o leitor o julgue.

O próprio formato dos dossiês mudou nas últimas décadas. Era habitual, nos anos 1980, haver dossiês sem apresentação específica; os artigos eram apenas publicados em conjunto sob um título único para o volume. Em outros casos a Apresentação, a cargo do Conselho Editorial, era bastante sumária e raramente fazia mais do que descrever os artigos publicados. Ultimamente a $\mathrm{RBH}$ vem pedindo aos organizadores apresentações mais densas, com algum tipo de discussão historiográfica que não só situe e justifique a temática abordada pelo dossiê, mas também se sustente enquanto contribuição acadêmica. Esperamos, com isso, que os dossiês aqui publicados tenham ganhado em relevância.

Desde que a $R B H$ assumiu o formato quadrimestral, a praxe tem sido a publicação de dois números com dossiês por ano, deixando um número exclusivamente para artigos avulsos, o que não exclui estes últimos de também serem publicados nos outros números. Desse modo, o leitor encontrará aqui dois artigos de temática diferente da do dossiê. Os textos retidos abordam ambos a realidade política dos anos 1960 no contexto de maior tensão da Guerra Fria. O primeiro, de autoria de Rodrigo Patto Sá Motta, revê, nos 50 anos de sua promulgação, e a partir de fontes inéditas, as origens do Ato Institucional 5, chamando a atenção para o seu uso como instrumento de controle de segmentos integrantes do próprio campo do regime. Jaime Yaffé, por sua vez, analisa a atuação do Partido Comunista Uruguaio levando em 
conta suas posições heterodoxas entre a retórica incendiária cubana e o caminho pacífico, por via democrática, ao socialismo.

Este número também traz três resenhas, duas delas com análises de obras que dialogam com a temática do dossiê: "Por escravos e libertos".

Ao lhes desejarmos uma boa leitura, não podemos deixar de agradecer ao Conselho Editorial, à Editoria Associada Internacional, aos Assistentes Editoriais Pablo Serrano e Marcus Vinicius Correia Biaggi, assim como à equipe de edição da $R B H$ - Armando Olivetti, Flavio Peralta e Roberta Accurso.

A $R B H$ não teria a qualidade que tem sem o apoio do Programa de PósGraduação em História, Cultura e Práticas Sociais da Universidade do Estado da Bahia (PPGHCPS-Uneb) e do CNPq.

Bruno Feitler

Universidade Federal de São Paulo (Unifesp), Escola de Filosofia, Letras e Ciências Humanas, Departamento de História. Guarulhos, SP, Brasil. rbh@anpuh.br <http://orcid.org/0000-0003-1468-5680>

\section{REFERÊNCIAS}

CALDEIRA, Ana Paula S. Editorial: o tempo das revistas. Varia Historia, Belo Horizonte: UFMG, n.65, 2018. http://dx.doi.org/10.1590/0104-87752018000200001.

GOMES, Ângela M. de C.; GUIMARÃES NETO, Regina Beatriz. Trabalho escravo contemporâneo: tempo presente e usos do passado. Rio de Janeiro: Ed. FGV, 2018. LARA, Silvia Hunold. Apresentação. Revista Brasileira de História, São Paulo: Anpuh, v.8, n.16, p.7-8, 1988.

\section{NOTAS}

${ }^{1}$ Enquanto os livros, por exemplo, teriam uma temporalidade mais longa (CALDEIRA, 2018).

${ }^{2}$ Veja o evento organizado também por Silvia Hunold Lara no dia 24 de setembro deste ano sobre as "Condições de trabalho no Brasil contemporâneo: políticas públicas e memória institucional” na Unicamp (programa disponível em: https://www.foruns.unicamp.br/ eventos/condicoes-de-trabalho-no-brasil-contemporaneo-1; acesso em: 29 out. 2018) e o livro recentemente publicado por Ângela de Castro Gomes e Regina Guimarães Neto (GOMES; GUIMARÃES NETO, 2018) sobre o trabalho forçado na Região Amazônica. 